\title{
Microbial Biomass and Activity in a Calcareous Soil Amended with Municipal Solid Waste Compost
}

\author{
Elsoury, A. H. A.E. Shouman ${ }^{1}$ and S.A.E.Abdelrazek \&H. M. Elkony ${ }^{2}$
}

\begin{abstract}
The dynamics of soil health indicators such as microbial biomass, urease and acid phosphatase activities, in a calcareous soil amended with different doses of Borg Elarab municipal solid waste compost (MSWC) were studied over 120 days of incubation at $30^{\circ} \mathrm{C}$ at $60 \%$ of soil water holding capacity. The parameters were found to increase with the increase in doses of MSWC. Soil microbial biomass (MB) activity reached peak values at 30 days of incubation and then gradually decreased up to 120 days of incubation. Urease and acid phosphatase activities showed peak values at 60 and 90 days of incubation, respectively. The increase in soil enzyme activities with the fall in MB suggested that the release of enzymes was associated with lysis of microbial cells at the end of their life cycle. There was no indication of any detrimental effect on soil health indicators of application of MSWC to soil
\end{abstract}

Keywords: Microbial Biomass, Calcareous Soil, Municipal Solid Waste, Compost, Borg Elarab

\section{INTRODUCTION}

The importance of manures, crop residues and other organic materials in maintaining soil health is widely recognized. The application of organic matter may increase crop yield through improvement of the physical, chemical and microbiological composition of the soil (EL-Kouny et al., 2004; 1999). Incorporation of lime sludge by plough less tillage $(10-12 \mathrm{~cm})$ resulted in significantly higher soil water content, better seedbed structure and greater crop germination rate., (Aleksandras et al., 2014). Liquid and solid manure applied in the top soil layers $(0-7.6 \mathrm{~cm})$, showed significant decreases $(10 \%)$ in soil bulk density in the top layers where manure had been applied, (Arriaga and Lowery, 2003). The organic matter status of tropical soils is inherently low. The design of management practices is therefore of fundamental importance in improving soil health (Doran and Safley, 1997; Doran et al., 1994; Haris and Bezdicek, 1994). The generation and disposal of municipal solid waste are impotent global environment issues. Recent attention has been directed towards conservation and reclamation of natural resources. Solid waste, ordinarily considered a nuisance, can be composted for recycling of waste materials. Investigations have ascertained both beneficial and adverse effects of municipal solid waste compost (MSWC). Unfavorable effects have been attributed to poor quality of compost related to maturity and stability (Jimenez and Garcia 1989). Another serious objection to MSWC relates to its content of heavy metals (Stratton et al., 1995), which depends on the source of raw materials from which the compost is derived. Heavy metals inhibit soil health indicators such as microbial biomass (Brookes and McGrath 1984) and activity (Tyler 1981). These microbial parameters are instrumental in nutrient cycling processes and could be used as indicators of soil health (Doran and Parkin, 1994). The effect of MSWC application to a calcareous soil, under laboratory conditions, on the dynamics of soil microbial biomass and microbial activities such as urease (UR) and phosphatase (AP) activities was the aim of this study.

\section{MATERIALS AND METHODS}

Surface soil (0-10 $\mathrm{cm}$ depth) was collected from a potato field in the Borg Elarab area, Alexandria, Egypt. Air dried, screened $(2 \mathrm{~mm})$ and preserved for analyses. MSWC was obtained from a composting facility set up by Borg Elarab Municipal Station. Solid waste was converted into compost by the aerobic fast fermentation process in windrows using microbial culture to enhance composting. The characteristics of the soil and MSWC, expressed on a moisture-free basis and analyzed by standard methods (Page et al., 1982 and EL-Kouny et al., 1999), are given in Table (1).

Incubation study: Each one $\mathrm{kg}$ of soil was well mixed thoroughly with the MSWC rate corresponding to 0 , $2.5,5,10$, and $20 \mathrm{tfed}^{-1}$; regarding that the composting application depth is $9 \mathrm{~cm}$ in the field (John et al, 2003) and then was placed in a plastic container of $14 \mathrm{~cm}$ height and $10 \mathrm{~cm}$ diameter, according to statistical design of treatments. Water was added to the soil /compost mixture to bring the moisture content to $60 \%$ water holding capacity.

\footnotetext{
${ }^{1}$ Research Institute of Agricultural Engineering

Agricultural Research Center, Egypt

Institute of Environment Studies Research

Ain Shams University, Egypt

${ }^{2}$ Soil, Water and Environment Research Institute,

Agriculture Research Center, Cairo, Egypt

E.mail: drhussien_elsoury@yahoo.com

Received August 20, 2015, Accepted September 20, 2015
} 
Table 1. Physico- chemical characteristics of municipal solid waste compost and calcareous soil

\begin{tabular}{|c|c|c|}
\hline Parameter & Compost & Soil \\
\hline Colour & Dark brown & 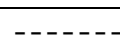 \\
\hline $\mathrm{pH}$ & 7.5 & 7.8 \\
\hline $\mathrm{EC}\left(\mathrm{dsm}^{-1}\right)$ & 2.5 & 0.93 \\
\hline WHC (\%) & 85 & 14 \\
\hline $\mathrm{MO} \%$ & 18.5 & 43.57 \\
\hline Soil texture & sandy & \\
\hline Sand $\%$ & ------ & 64.85 \\
\hline Silt $\%$ & $-\cdots--$ & 12.05 \\
\hline Clay $\%$ & $-\cdots--$ & 23.10 \\
\hline Bulk density $\left(\mathrm{g} / \mathrm{cm}^{3}\right)$ & 0.61 & 1.71 \\
\hline Organic C (\%) & 20 & 0.75 \\
\hline Total N (\%) & 1.2 & 0.2 \\
\hline $\mathrm{C} / \mathrm{N}$ & 16.67 & ND \\
\hline $\mathrm{CEC}\left[\mathrm{Cmol} / \mathrm{kg}^{-1}\right]$ & 81 & 8.00 \\
\hline Total humus (\%) & 22 & ND \\
\hline \multicolumn{3}{|c|}{ Compost-C day ${ }^{-1}$ at $22{ }^{\circ} \mathrm{C}$} \\
\hline Microbial biomass $\left(\mathrm{mgkg}^{-1}\right)$ & 1709 & \\
\hline \multicolumn{3}{|c|}{ Heavy metals $\left(\mathrm{mgkg}^{-1}\right)$} \\
\hline Total Zink: & 502 & $\begin{array}{ll}------- \\
\end{array}$ \\
\hline Total Copper: & 167 & -------- \\
\hline Total Cadmium: & 1.7 & -------- \\
\hline Germination index & 94 & -------- \\
\hline
\end{tabular}

$\mathrm{ND}=$ not determined

The plastic containers were then incubated in the dark for 120 days at $30^{\circ} \mathrm{C}$. The moisture content was maintained throughout the incubation period by adding required amounts of sterile distilled water. The experiment had a factorial completely randomized design with 2 replicates. Factor A was 5 levels of MSWC; $0,2.5,5,10$, and $20 \mathrm{tfed}^{-1}$ added to the soil. Factor B was 7 levels of incubation periods; 10, 20, 30, $45,60,90$, and 120 days. The treated soil was collected periodically and analyzed. Microbial biomass (MB) in soil was measured by fumigation- extraction method (Joergensen, 1995) and Alef (1995). Urease (UR) and phosphomonoesterase in soil were measured according to Tabatabai and Bremner (1972) and Tabatabai and Bremner (1969) respectively.

\section{RESULTS AND DISCUSSION}

Compost quality: Stipulated norms for compost quality assessment by physical, physico-chemical, chemical, microbiological, Biochemical and biological methods are proposed (Epstein 1997, Mondini et al. 1997). The organic-C content, total $\mathrm{N}$ content and water holding capacity of the compost were optimal; however, a high electrical conductivity demanded attention. Based on properties such as colour, $\mathrm{pH}, \mathrm{CEC}$ (cation exchange capacity), total humus and microbial biomass, the compost could be graded as stable and mature. Biologically, the compost was not phytotoxic as determined by germination index test (Keeling et al. 1994). Total zinc, copper and cadmium contents of the compost were above critical level (Epstein, 1997), which require careful monitoring on application to soil.

Microbial biomass: The variations in soil MB between treatments and periods were statistically significant Table (2). A marked increase in soil $\mathrm{M}$ was found for each increase in dose of MSWC from 2.5 to $20 \mathrm{t} \mathrm{fed}^{-1}$. MB in the treated soil mixture, were significantly higher than the MB in the control. Elsokkary et al., (2011) reported increases in soil $\mathrm{MB}$ at 20 and $80 \mathrm{t} \mathrm{fed}^{-1}$ MSWC application rates to soil. Such increase in soil MB was probably caused by the higher level of soluble organic-C in MSWC- enriched soils. In composttreated soils, the soil $\mathrm{MB}$ reached peak values at 30 days of incubation and decreased gradually, with the lowest value at 120 days. However, in the control treatment the soil MB started declining from 10 days onwards. Availability of biogenic material for biomass stimulation (Jenkinson and Ladd 1981) induced the increase in soil MB of enriched soils. The initial 
increase may also correspond to the growth of the zymogenous population associated with organic matter enriched (Jenkinson et al., 1987) and incorporation of exogenous microorganisms (Perucci 1992). The observed decline in soil MB after 30 days, consistent with the work carried out by Sparling (1985), may be associated with a nutrient shortage or the 'protective capacity' of the soil biomass. Excess biomass generated beyond that capacity is automatically killed or lysed, resulting in lower biomass.
Enzyme activities: Both the urease (UR) and acid phosphatase (AP) activities in the soil were increased significantly by the increase of MSWC dose as compared to the control treatment (Tables 3 and 4). The activity of UR in the soil increased up to 60 day and then declined at 120 day. In contrast, the acid phosphatase activity in the soil increased up to 90 day, irrespective of treatment, and then declined at 120 day. The dynamics of UR and AP activities in the soil did not follow the trend of MB.

Table 2. Dynamics of Microbial biomass in calcareous soil amended with graded doses of municipal solid waste compost from Borg Elarab station

\begin{tabular}{lcccccccc}
\hline \multicolumn{7}{c}{ Microbial biomass $\left(\boldsymbol{\mu g g} \mathbf{- 1}^{-1}\right.$ soil) } \\
\hline & $\mathbf{1 0}$ & $\mathbf{2 0}$ & $\mathbf{3 0}$ & $\mathbf{4 5}$ & $\mathbf{6 0}$ & $\mathbf{9 0}$ & $\mathbf{1 2 0}$ & Mean \\
\hline Treatment (T) & & & & & & & & \\
\hline Control & 72 & 53 & 35 & 26 & 23 & 18 & 18 & 35 \\
\hline $2.5 \mathrm{t}$ fed & 92 & 101 & 106 & 92 & 93 & 56 & 52 & 85 \\
\hline $5 \mathrm{t}$ fed & 120 & 123 & 137 & 114 & 108 & 72 & 69 & 106 \\
\hline $10 \mathrm{t}$ fed & 136 & 160 & 174 & 149 & 121 & 93 & 79 & 130 \\
\hline $20 \mathrm{t}$ fed & 153 & 198 & 205 & 176 & 148 & 121 & 109 & 159 \\
\hline Mean & 115 & 127 & 131 & 111 & 99 & 72 & 65 & \\
\hline
\end{tabular}

$\operatorname{LSD}(\mathrm{p}<0.05)$ for $\mathrm{T}=10.06 ; \mathrm{P}=11.90 ; \mathrm{P} * \mathrm{~T}=26.64$

Table 3. Dynamics of urease activity in calcareous soil amended with graded doses of municipal solid waste compost from Borg Elarab station

\begin{tabular}{|c|c|c|c|c|c|c|c|c|}
\hline \multicolumn{9}{|c|}{ Urease activity ( $\mu$ g urea hydrolyzed $\mathrm{g}^{-1}$ soil $^{-1}$ at $37^{\circ} \mathrm{C}$ ) } \\
\hline \multicolumn{9}{|c|}{ Period (P) (days of incubation) } \\
\hline \multirow{2}{*}{\multicolumn{9}{|c|}{ Treatment (T) }} \\
\hline & & & & & & & & \\
\hline Control & 19 & 22 & 28 & 32 & 37 & 23 & 13 & 25 \\
\hline $2.5 \mathrm{t}$ fed & 29 & 33 & 38 & 40 & 49 & 36 & 15 & 34 \\
\hline $5 \mathrm{t}$ fed & 33 & 36 & 40 & 49 & 58 & 42 & 24 & 40 \\
\hline $10 \mathrm{t}$ fed & 37 & 47 & 51 & 55 & 61 & 48 & 32 & 47 \\
\hline $20 \mathrm{t}$ fed & 43 & 51 & 56 & 66 & 74 & 62 & 37 & 56 \\
\hline Mean & 32 & 38 & 43 & 48 & 56 & 42 & 24 & \\
\hline
\end{tabular}

$\operatorname{LSD}(\mathrm{p}<0.05)$ for $\mathrm{T}=4.52 ; \mathrm{P}=5.35 ; \mathrm{P} * \mathrm{~T}=$ not significant

Table 4. Dynamics of Acid phosphatase activity in calcareous soil amended with graded doses of municipal solid waste compost from Borg Elarab station

\begin{tabular}{|c|c|c|c|c|c|c|c|c|}
\hline \multicolumn{9}{|c|}{ Acid phosphatase activity ( $\mu$ g paranitrophenol released $\mathrm{g}^{-1}$ soil $\mathrm{h}^{-1}$ at $\left.37^{\circ} \mathrm{C}\right)$} \\
\hline \multicolumn{9}{|c|}{ Period (P) (days of incubation) } \\
\hline Treatment (T) & 10 & 20 & 30 & 45 & 60 & 90 & 120 & Mean \\
\hline Control & 124 & 127 & 137 & 178 & 177 & 202 & 202 & 164 \\
\hline $2.5 \mathrm{t}$ fed & 173 & 189 & 201 & 247 & 258 & 274 & 269 & 230 \\
\hline $5 \mathrm{t}$ fed & 199 & 208 & 218 & 261 & 279 & 284 & 277 & 247 \\
\hline $10 \mathrm{t}$ fed & 209 & 247 & 276 & 304 & 317 & 343 & 337 & 290 \\
\hline $20 \mathrm{t}$ fed & 227 & 256 & 279 & 320 & 342 & 394 & 391 & 116 \\
\hline Mean & 187 & 206 & 222 & 262 & 275 & 300 & 295 & \\
\hline
\end{tabular}

$\overline{\mathrm{LSD}}(\mathrm{p}<0.05)$ for $\mathrm{T}=4.83 ; \mathrm{P}=5.72 ; \mathrm{P} * \mathrm{~T}=12.77$. 
The increase in soil enzyme activities followed the decrease of MB suggested that the release of the enzymes was linked to lysis of microbial cells at the end of their life cycle (Perucci, 1990).

Results showed that addition of MSWC in doses as high as 20t fed-1 did not have a detrimental effect on soil health indicators such as MB and enzyme activities.

\section{CONCLUSION}

In this current work, microbial biomass, urease and acid phosphatase activities, in a calcareous soil amended with different doses of Borg Elarab municipal solid waste compost (MSWC) were studied as dynamics of soil health indicators. $\mathrm{MB}$ in the treated soil mixtures, were significantly higher than the $\mathrm{MB}$ in the control. Both the urease (UR) and acid phosphatase (AP) activities in the soil were increased significantly by the increase of MSWC dose as compared to the control treatment. The dynamics of UR and AP activities in the soil did not follow the trends of MB. The increase in soil enzyme activities followed the decrease of MB suggested that the release of the enzymes was linked to lysis of microbial cells at the end of their life cycle. Results showed that addition of MSWC in doses as high as $20 \mathrm{ted}^{-1}$ did not have a detrimental effect on soil health indicators.

\section{REFERENCES}

Aleksandras VELYKIS, Antanas SATKUS, Laura MASILIONYTE் (2014): Effect of tillage, lime sludge and cover crop on soil physical state and growth of spring oilseed rape Zemdirbyste-Agriculture, vol. 101, No. 4 (2014), p. 347-354 DOI 10.13080/z-a.2014.101.044

Arriaga, F.J., and Lowery, B., (2003). Soil physical properties and crop productivity of an eroded soil amended with cattle manure. Soil Science. 168:888-899.

Alef, K., (1995): Estimation of soil respiration. In: K, Alef and PNannipieri (eds), Methods in Applied Soil Microbiology and Biochemistry, pp. 215 -216. Academic Press_Harcourt Bracem London.

Brookes,P. C., and McGrath S. P. (1984): Effect of metal toxicity on the size of soil microbial biomass. J. soil Sci. 35, 341-346.

Doran J.W., and Parkin T. B., (1994): Defining and assessing soil health. In: J W. Doran,D. C. Coleman. D.F. Bezidcek and B. A. Stewart (eds), Defining Soil health for Sustainable Environment.Special Publication 35. pp. 3-21. Soil Sci.Soc. Am. Inc., Madison,WI.

Doran J.W., and Safley, M. (1997): Defining and assessing soil health and sustainable productivity in 'Biological indicators of soil health'. Eds CE Pankhurst BM Doube and VVSR Gupta, pp 1-28 CAB International, Wallingford
Doran, J.W., Sarrantonio, M. and Janke, R. (1994): Strategies to promote soil quality and soil health. In: Pankhurst. C.E., Doube, B. M., Gupta, V.V.S.R. and Grace P.R. (eds) Soil Biota: Management in Sustainable Farming Systems. CSIRO Press, Melbourne, pp. 230 -237.

Epstein, E., (1997): The Science of Composting. Tech-nomic Publishing Co. Inc. Lancaster, PA.

El-Kouny, H.M. (1999): Evaluation of compost production and its properties with special reference to compost extracted. Ph.D.Thesis, Fac. Agric.. Alex.Univ,Egypt.

El-Kouny, H.M., El-Assar, A.M. and Mohamed, S.G. (2004): Effectiveness of natural organic amendments biologically activated composted and mineral fertilization sources of potassium in improving soil properties and productivity of "Zaghloul cv." date pal in calcareous soil. Assiut J. Agric. Sci.. 25:2.

Elsokkary, I.H., Abd El-All, A. E. and Gomaa, H. E. (2011): Microbial Biomass and Respiration of Soil Cultivated with Wheat Grown on Calcareous Soil as Influenced by Nitrogen Fertilization, Biofertilization and Farmyard Manure Application. Alex. Sci. Exchange J. 32 (4) 467478

Garcia-Gil, J., Plaza, C., Soler-Rovira, C. P., and Polo, A. (2000): Long-term effects of municipal solid waste compost application on soil enzyme activities and microbial biomass. Soil Biol. Biochem. 32, 1907 - 1913.

Haris, R,F, and Bezdicek, D. F.(1994): Descraptive aspects of soil quality/health. In: Doran, J.W., Coleman, D.C., Bezdicek, D. F. and Stewart, B.A. (eds) Defining Soil Quality for a Sustianable Environmental. Soil Sience Socity of Amirica Inc. Special Publication No. 35, Madison, Wisconsin, USA, pp. 23-35.

Jenkinson, D. S. and Ladd, J. N. (1981): Microbial biomass in soil: measurement and turnover. In: E. A Paul and J. N. Ladd (eds), Soil Biochemistry,Vol. 5،pp. $415 Đ 471$. Marcel Dekker Inc., New York.

Jenkinson, D. S., Hart, P. B. S., Rayner, J. H. and Parry, L. C. (1987): Modelling the turnover of organic matter in longterm experiments at Rothamsted. Intecol Bull. 15, $1 Đ 8$. Jimenez, I. E., and P. V. Garcia, 1989: Evaluation of cityrefuse compost maturity: a review. Biol. Wastes 27 ، $115 Đ 142$.

Jimenez and Garcia (1989): Nitrogen availability from a mature urban compost determined by the ${ }^{15} \mathrm{~N}$ isotope dilution method, Cordel de Merinas 40-52, 37008 Salamanca (Spain).

Joergensen, R. G., (1995): Microbial biomass. In: K. Alef and P. Nannipieri (eds), Methods in Applied Micro- biology and Biochemistry, Ch. 8, pp. 382Đ386. Academic Press, London. 
John, R., Sherry, M., Bruce, H., Jan, J., John, L. and Mauric,, E. W., (2003). Recmmended Methods of Manure Analysis, University of Wisconsin Madison, Cooperative Extension puplishing.

Keeling, A. A., Paton, I. K., and Mulett, J. A. J. (1994): Germination and growth of plants in media contain- ing unstable refuse-derived compost. Soil Biol. Bio- chem. 26, $767 Đ 772$.

Mondini, C., Sanchez-Monedero, A., Leita, L., Bragato, G. and De Nobili, M. (1997): Carbon and ninhydrin reactive nitrogen of the microbial biomass in rewetted compost samples. Commun. Soil Sci. Plant Anal. 28, $113 Đ 122$.

Page, A. L., Miller, R.H. and Keeny, D. R. (1982): Methods of soil analysis. Part 2: Chemical and biological Properties, $2^{\text {nd }}$ ed., No. 9 (part) in the series Agronomy, American Society of Agronomy, Inc. Madison. Wisconsn, USA.

Perucci, P., (1990): Effect of the addition of municipal solid waste compost on microbial biomass and enzyme activities in soil. Biol. Fertil. Soils 10, 221Đ226.
Perucci, P., (1992): Enzyme activity and microbial biomass in a ${ }^{\circledR}$ eld soil amended with municipal refuse. Biol. Fertil. Soils 14, 54Đ60.

Sparling, G. P., (1985): The soil biomass. In: D. Vaughan and R. E. Malcolm (eds), Soil Organic Matter and Biological Activity, p. 223. Martinus Nijo /Dr W.Junk, Dordrecht.

Stratton, M. L., Barker, A. V., and Rechcigl, J. E. (1995): Compost. In: J. E. Rechcigl (ed.), Soil Amendments and Environmental Quality. Lewis Publishers، New York.

Tabatabai, M. A., and Bremner, J. M. (1969): Use of pnitrophenyl phosphate for assay of soil phosphatase activity. Soil Biol. Biochem. 1, $301 Đ 307$.

Tabatabai, M. A., and Bremner, J. M., (1972): Assay of urease activity in soils. Soil Biol. Biochem. 4, 479Đ487.

Tyler, G., (1981): Heavy metals in soil biology and biochemistry. In: E. A. Paul and J. N. Ladd (eds), Soil Biochemistry, Ch. 5, pp. 371-413. Marcel Dekker Inc., New York .

\section{الملخص العري}

\section{معل ششلا الكتلة الحيويةف الاراضف الجيربة المعاملة بكمبوست مخلفلت المنازل الصلبة المكمور}

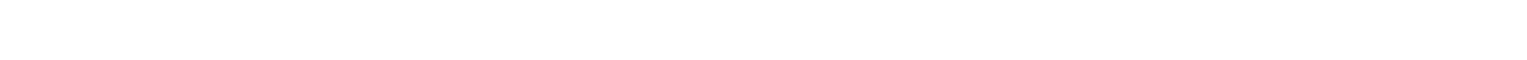

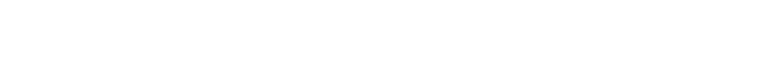

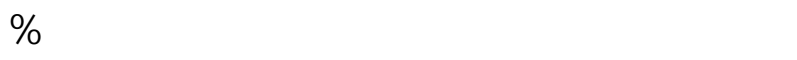
من المعة المائية للتربة. اوضحته النتائج ان القيم المتحصل

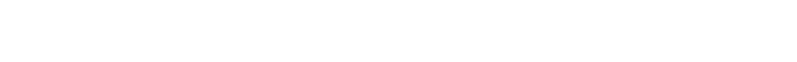

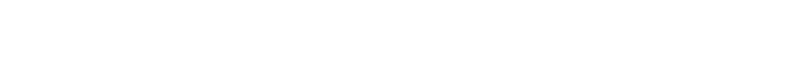

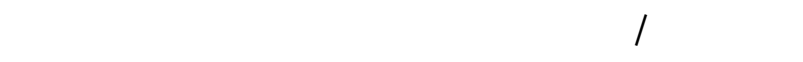

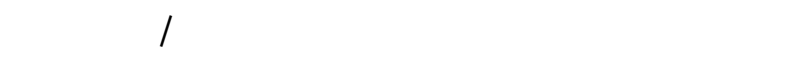

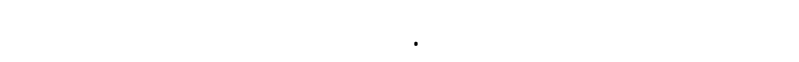

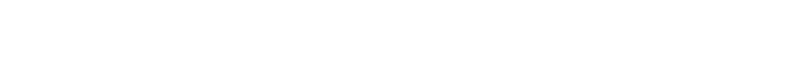

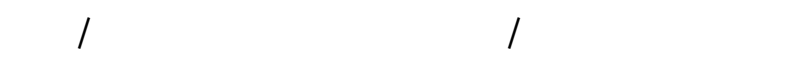
تربه على التواله، وان الزياة فى النزيمكت التربة ارتبطت

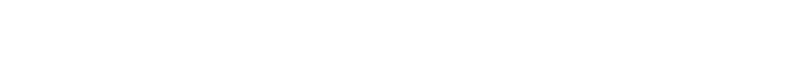

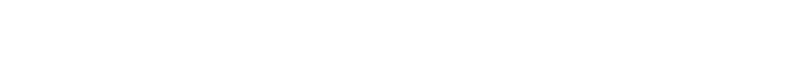

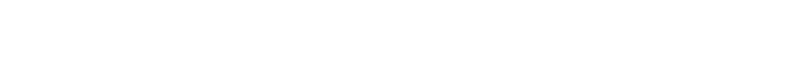
تمت الدرلمة.

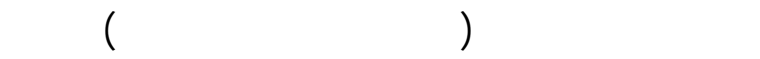

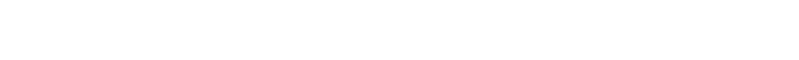
ومعدلات اضفتتها. ويمكن وصف هذه الحيوية من خ لاله بعض المؤشرات مل نشط الكتلة الحيوية ونشط النزيمكات اليوريز والفونفاتيز الحمض. وهذ ـك فولئ د و وس لمبيلت

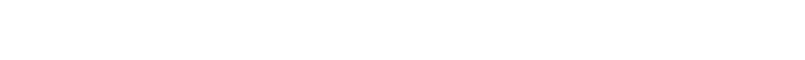

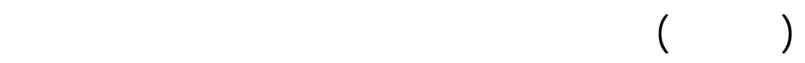

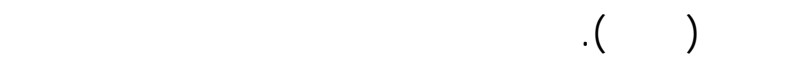

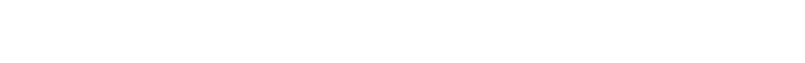

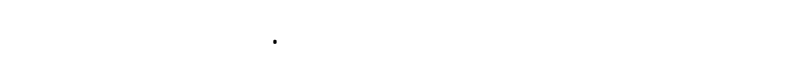
البهث هو درلمة تاثيرممدلات التسميد بكمبوست المنكور

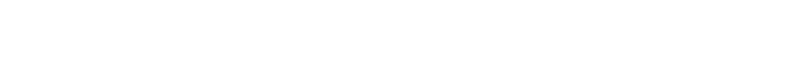

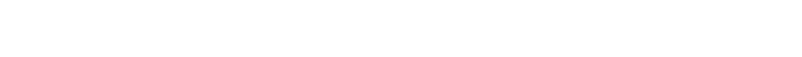
الظروف المتحكم فيها معمليا. 